\title{
THE IMPORTANCE OF PUBLIC CONTROL IN BUILDING A DEMOCRATIC STATE BASED ON THE RULE OF LAW AND THE FORMATION OF CIVIL SOCIETY AND IN THE MANAGEMENT OF SOCIETY
}

\author{
Jaloliddin Ne'matjonovich Polvanov \\ Lecturer National University of Uzbekistan named after Mirzo Ulugbek \\ Tashkent, Uzbekistan
}

\begin{abstract}
BSTRACT: This article discusses the formation of views on a democratic state governed by the rule of law and civil society. The article also discusses the state guarantees and support for the protection of non-governmental organizations. In legal democracies, strong governance is largely the responsibility of civil society institutions. At the same time, the direct participation of the public in the implementation of governance will be expanded. A self-governing society is based on strong nongovernmental structures.
\end{abstract}

EY WORDS: Non-governmental organizations, civil society institutions, democracy, the rule of law, democratic society, civil society, legal citizenship.

\section{NTRODUCTION}

Today we live in a truly historic time. Independence has given us the opportunity to live in freedom and liberty, to shape our national values and culture in a new way, which has truly won the admiration of the world. From the first days of independence, our first President said that building a democratic state based on the rule of law and a just civil society is our main concept. Today, the idea of moving from a strong state to a strong society has become one of the most important aspects of society.

In the developed countries of the world, mainly civil society institutions, in particular, non-governmental non-profit organizations, are actively involved in the management of society. That is, a strong state will gradually transfer its functions to non-governmental non-profit organizations. In a strong society, citizens have a high level of social activism and political outlook.

Opinions about a democratic state governed by the rule of law and civil society have been formed in our country since independence. Ideas about a democratic state governed by the rule of law and civil society, including democracy, the rule of law, democratic society, civil society, are based on the works, speeches and speeches of the first President of the Republic of Uzbekistan I.A. Karimov. At present, scientists of the republic are conducting research in this area.

"The essence of democracy is the belief that human dignity is above all else".

"The essence of true democracy is the harmonization of interpersonal, interethnic, state and socio-political relations. In this, man and society, society and state power live in peace". 
Oriental Journal of History, Politics and Law Vol.1 (1), pp.04-08, 23 May, 2021 Available online at http://supportscience.uz/index.php/ojhpl (C) 2021 Support Science LLC

DOI: https://doi.org/10.37547/supsci-ojhpl-01-02

Democracy is, first of all, the rule of the people. It is one of the basic tenets of government.

\section{ETHODS}

"Democracy means that power belongs only to the people, that the state must serve the will, expression and interests of the people, and that the policy pursued by the state is aimed only at ensuring the well-being of man and society. Democracy means that power is exercised only through the bodies established by the Constitution and laws and in accordance with them. Government agencies shall act only within the limits of their powers provided by law. " From this point of view, a democracy is based on the rule of law. Every activity is carried out in accordance with the Constitution and laws. Individuals will have a high level of legal awareness.

"The issue of the rule of law is one of the most important and topical issues of our time, which has a scientific, theoretical and political significance, and its creation and functioning is a historic task facing our society. Therefore, the preamble to the current Constitution of the Republic of Uzbekistan enshrines in law the goal of "building a humane democratic state governed by the rule of law." The inclusion of this goal in the agenda is determined by a number of factors and conditions, based on the policy of statehood and the development of law".

"The goal of building a state governed by the rule of law stems from the fact that in the context of independence and the transition to market relations, the regulation of social relations in our society by legal norms is a very important and urgent task. The scope of legal values today, the vital need for them, is enormous. Because legal norms regulate a wide range of economic, social, political and cultural relations between individuals and legal entities, the state and citizens. The need for the rule of law shows not only the growing role of the rule of law in building a new democratic society, but also the significant role of the state in governing the country"

"The rule of law is a state formed on a legal basis and the rule of law prevails in all spheres of public life."

"The rule of law is a democratic state based on the rule of law, the rule of law, equality before the law and an independent judiciary, guaranteed human rights and freedoms, and the separation of powers."

It is clear from the above definitions that in a state governed by the rule of law, the rule of law prevails, human rights and freedoms are guaranteed, and all conditions are created for their free development.
There are signs of the rule of law, including the rule of law, the supremacy of the Constitution and laws, the protection of human rights and freedoms, the mutual responsibility of the state and the citizen, the legitimacy and separation of powers, the independence of the judiciary and its rule of law. the higher the level of legal consciousness and culture, and so on.

Thus, the main feature of a state governed by the rule of law is that it operates within the rule of law, and that all its relations with society and man are governed by legal norms. In turn, the law is exercised voluntarily and through the influence of the state. Government agencies, officials and legal entities, public associations and citizens are directly involved in the formation and operation of the rule of law.

Civil society is formed together with the rule of law. It is impossible to imagine them without each other. This process is determined by the socio-economic, cultural development of society, the creation of its scientific and technical basis.

"The rule of law is, in essence, a political expression of civil society. An inseparable and intertwined civil society and the rule of law can be a symbol of the integrity of society".

At the heart of legal relations in civil society, along with legal norms and their sanctions, are human qualities such as conscience, duty, a sense of responsibility, internal discipline, and, in short, legal citizenship."

"Civil society guarantees human rights, and the state guarantees the rights of citizens."

Civil society, like the rule of law, has its own characteristics. These are mainly reflected in its economic, political, social and spiritual aspects.

First of all, it is based on the market economy relations, which open the way to private property and are based on it, and the conditions for free economic activity.

In the second aspect, the political-legal system and the essence of governance represent the rule of law.

The third aspect is the family, the self-governing bodies, and the civilized ways of defining, shaping, and expressing public opinion..

Fourthly, it is based on spiritual, high-cultural human relations. H. Odilkariyev describes civil society as follows: "Civil society is a state that prioritizes the interests of every person, creates an atmosphere of respect for legal traditions and laws, respects universal values, unconditional guarantee of human rights and freedoms. a free democratic legal society based on deep spiritual and cultural values of human relations, which have created effective mechanisms of public control of the government. 
Oriental Journal of History, Politics and Law Vol.1 (1), pp.04-08, 23 May, 2021 Available online at http://supportscience.uz/index.php/ojhpl (C) 2021 Support Science LLC

DOI: https://doi.org/10.37547/supsci-ojhpl-01-02

Speaking of civil society, it should be noted that the ideas about it have been formed for a long time and are interpreted and analyzed in a certain way today. However, civil society is full of unresolved issues. The definitions given to him are also different. But in all of them, the human factor is given priority, and the rights and interests are guaranteed.

Civil society, unlike society, is formed at a certain stage of development. First of all, there must be sufficient conditions, economic, political, legal and moral foundations. Without them, the formation of civil society is a complex process.

The role of the state in civil society will be significantly reduced, but the state will retain its core functions. For example, ensuring security, inviolability of the country's territory, resolving public finances, etc. The reason why the state retains control over the areas that are important for the life of the country is that if these areas are transferred to different organizations, they can serve different interests.

It is noteworthy that civil society, through its structures, can influence the actions of the state, and the opinion of the population is more important in its decisionmaking.

It should be noted that civil society is not only a society of equal citizens, but also a society that provides the necessary conditions for them. In civil society, the Constitution and laws take precedence, which promotes the self-improvement of each person, the full realization of the interests, rights and freedoms of the individual, as well as the observance of the rules established by law. it also requires them to adhere strictly and perform their duties.

The movement of civil society is also determined by the degree of formation of public associations. "Public associations are organizations that are independent of the state, operate separately and, at the same time, can influence state institutions, aimed at protecting the state from interference in public life, as well as in the private lives of citizens."

The individual is the central society in civil society, in which the legal consciousness and culture of individuals are sufficiently formed, and all measures are taken and conditions are created for its formation. Everyone will have the opportunity to express their views on each reform.

Thus, civil society is a society that is formed at a certain stage of development, ensures human rights and freedoms, a decent lifestyle, the rule of law, and performs certain functions of the state.
State guarantees of protection of non-governmental non-profit organizations and issues of their support

The existence of such a special fund will ensure the full independence of non-governmental organizations, local self-government bodies and democratic institutions. The success of the newly formed nongovernmental and public organizations in finding their place in society in the short term, in the proper financing of beneficial programs and projects, and in strengthening their material and technical base will depend on this fund in the future.

The new bill should focus on building and maintaining a balance, cooperation and non-subordination between the foundation and non-governmental, public organizations and other civil society institutions.

The draft law provides for the status of the fund, its structure, the order of its management, the legal force, action and scope of the documents adopted by it, its interaction with other non-governmental and public structures, its rights and obligations, financial resources and the formation of revenues. A number of important issues should be reflected, such as the procedure, distribution of funds, accounting and control of expenditures, the order of consideration of proposed projects for funding, the relationship of the Fund with government agencies.

In the UK, for example, the Commission on Public Organizations deals with the provision of benefits to NGOs, grants and taxation. The Commission shall hold relevant negotiations with the Association of NonGovernmental Non-Profit Organizations in the interests of the state. Any public organization may receive additional benefits on the basis of the conclusion and consent of the commission. The status of the commission is determined by the relevant laws.

Ensuring the full independence of non-governmental organizations and other civil society institutions also depends on the organizational and legal structure of the above-mentioned fund.

In general, the great attention paid by the head of our state to the development of non-governmental, public structures is one of the important steps in building a strong civil society.

\section{ESULTS AND DISCUSSION}

Indeed, the importance of public oversight in the process of building a just society is immeasurable. Because the activity of every citizen in civil society, indifference to social events, full and correct understanding of the responsibilities of every leader in government, a deep sense that their activities are 
Oriental Journal of History, Politics and Law Vol.1 (1), pp.04-08, 23 May, 2021 Available online at http://supportscience.uz/index.php/ojhpl (C) 2021 Support Science LLC

DOI: https://doi.org/10.37547/supsci-ojhpl-01-02

under public control - in the development of society important.

Proper organization of public control is, first of all, important in ensuring the rule of law, preventing violations, identifying their causes and conditions, educating citizens in the spirit of strict adherence to the rule of law.

The question of what public control is and in what circumstances it can be answered is as follows.

First of all, it should be noted that the establishment of citizens' control over government agencies is not a matter of yesterday or today. If we look at history, we can see that this area of the democratic institution, which we call "public control" today, has worked in one way or another.

Sahibkiran Amir Temur gave great rights to the representatives of the noble people in governing the state. For example, in "Temur Tuzuklar" it is written: "I was aware of the situation of the population of every land. I have appointed religious and correct writers to write to me about the situation in each country, the mood of the people, their way of life, their actions, and the connections between them. Whenever I was told what they had written, I punished them. Whenever I heard of any of the governors and soldiers oppressing the people, I immediately took action against them for justice and fairness."

It is obvious that in the Timurid kingdom, too, in a unique form and style, the people, that is, the public control, was established. This means that a kind of public control is exercised by informing the owner of the real situation in one or another part of the kingdom..

Now let's take a look at public control in the recent Soviet empire. One of the most dangerous aspects of the former Soviet ideology was the false notion that non-existent democratic institutions formed the basis of the life of the state and society.

Organizations whose name is connected with the people and aimed at protecting the rights and interests of citizens, in fact, protect only the interests of the state, according to their organizational formations, programs, goals and objectives are true state structures and can not protect the interests of the people they were.

Uzbekistan's independence and the adoption of our Constitution have provided an opportunity to exercise public control, which is one of the most important institutions of a truly civil society. Over the years, the legal framework for public control in our country has been created in a sense. According to the Law on Citizens "Self-Government Bodies, citizens" assemblies have the right to hear reports of heads of district and city khokimiyats on issues related to the activities of self-government bodies and other similar powers. have had.

The Law of the Republic of Uzbekistan "On NonGovernmental, Non-Profit Organizations" also provides effective mechanisms to ensure the rule of law in the context of building a strong civil society, strengthening public control over the implementation of human rights and freedoms.

State control is exercised by officials (supervisors) of a particular state body with authority, but not in public control. Therefore, the legal status of the subject of public control always changes depending on the object of control, and it never becomes a "supervisor". Of course, being a subject of public oversight does not require special knowledge or specialization, such as "oversight." They are not funded by the state and do not have benefits.

Unlike subjects of state control, subjects of public control do not apply legal sanctions (criminal, administrative, disciplinary, etc.).

Public control is one of the social phenomena that occurs by the order of duty and conscience. Violations detected by public scrutiny cannot be hidden from the public.

From the above, it is clear that public control has several advantages over state control, and its effectiveness is high. This is not to say that state control should be abolished. Of course, strong and effective state control is an important area in any society.

We believe that the effectiveness of public oversight, which is necessary for the development of our society, can be seen in the following factors.

The formation of a strong civil society, the creation and improvement of its mechanisms are in the focus of scientists and experts.

Many scholars argue that political parties should play a key role in building a strong civil society. Professor S. Juraev, Candidate of Political Science, Associate Professor M. Kyrgyzbaev said that political parties are more active than other public organizations and their role should be high, as they are mainly engaged in political issues. confess.

Doctor of Political Sciences, Professor I. Ergashev 
Oriental Journal of History, Politics and Law Vol.1 (1), pp.04-08, 23 May, 2021 Available online at http://supportscience.uz/index.php/ojhpl (C) 2021 Support Science LLC

DOI: https://doi.org/10.37547/supsci-ojhpl-01-02

argues that in a strong civil society, a well-rounded person and his spiritual maturity play an important role. He believes that if a person is spiritually mature, it will be easier to form a civil society.

Professor M. Bekmurodov connects his views in this area mainly with the results of sociological research. In his opinion, the formation of a strong civil society with a national mentality (character) is important. Because our historical roots, the living conditions and worldviews of our ancestors still have an impact today, which can affect the development of society in one way or another.

\section{Conclusion}

In short, the main goal of developing democratic institutions is to involve as many people as possible in the construction of society, to make them the full owners of their own destiny, their own future.

\section{REFERENCES}

1. The Constitution of the Republic of Uzbekistan. Tashkent: O'zbekiston, 2003.-p. 40.

2. Karimov IA Uzbekistan: national independence, economy, politics, ideology. Tashkent: O'zbekiston, 1996. -p. 364.

3. Karimov I.A. Man, his rights, freedoms and interests are the highest value. People's Speech, December 10, 2005.

4. Bakhriyev K. "Democracy and Human Rights." 1999, Sharq Publishing House.

5. Kyrgyzbaev M. Civil society: political parties, ideologies, cultures. 1998, Sharq Publishing and Publishing Concern.

6. Saidov A., Todjixonov U. Theory of legal culture, 2000, Tashkent "Academy".

7. Jumayev R. The state and society: on the path to democratization. 1998

8. Каримов, Н. Р. (2018). ВКЛАД МУХАММАДА МАНСУРА АЛИ В ИЗУЧЕНИЕ НАУЧНОГО НАСЛЕДИЯ АБУ ИСА ТЕРМИЗИ. In НАУКА И ИННОВАЦИИ В ХХІ ВЕКЕ: АКТУАЛЬНЫЕ ВОПРОСЫ, ОТКРЫТИЯ И ДОСТИЖЕНИЯ (pp. 198-200).

9. Rustamiy, S., Lutfullaeva, D., \& Gulomova, H. (2020). THE IMPORTANCE OF BALAGHA SCIENCE IN AESTHETIC EDUCATION. PalArch's Journal of Archaeology of Egypt/Egyptology, 17(6), 8882-8886.

10. Каримов, Н. Р. (2018). КРАТКИЙ ОБЗОР РАБОТ БЕРУНИ И ЕГО РОЛИ В ЧЕЛОВЕЧЕСКОЙ ЦИВИЛИЗАЦИИ. In
Лучшая студенческая статья 2018 (pp. 85-91).

11. Rustamiy, S. A. (2020). Content of components of the science balagat. ACADEMICIA: An International Multidisciplinary Research Journal, 10(10), 1332-1337.

12. Дониёров, А. Х., \& Каримов, Н. Р. (2018). " КИТАБ АЛ-ХИКМА" И" ХИКМА" В НАУЧНОМ НАСЛЕДИИ ХАКИМА ТИРМИЗИ. In ЛУЧШАЯ НАУЧНАЯ СТАТЬЯ 2018 (рp. 48-52).

13. Khudoyberdiyevich, D. A., \& Rakhmonkulovich, N. K. (2018). The contribution of sarah sviri to the study of the scientific heritage of hakim tirmidhi. ACADEMICIA: An International Multidisciplinary Research Journal, 8(11), 6067.

14. Rustamiy, S. A. (2020). Content of components of the science balagat. ACADEMICIA: An International Multidisciplinary Research Journal, 10(10), 1332-1337.

15. SAIDAZIMOVA, U. T. (2021). The issue of two women in the korean art world. Journal of Contemporary Issues in Business and Government, 27(3), 303-308.

16. Saydazimova, U., \& Murodova, D. (2021). In Lee Bom Son's Story "Stray Bullet", the Issue of the Negative Consequences of the Civil War is Highlighted. Psychology and Education Journal, 58(1), 1138-1144.

17. Umida, S. (2019). Special genres in Korean and Uzbek literature: Their similarities and specific features. International Journal of Scientific and Technology Research, 8(12), 1264-1268.

18. Rustamiy, S. (2018). Typological peculiarties of science of balaghah, rhetoric and stylistics. The Light of Islam, 2018(1), 16.

19. Сайдазимова, У. Т. (2019). СОЗВУЧИЕ ТЕМЫ ЛЮБВИ К РОДИНЕ В ПОЭТИКЕ КИМ СОВОЛЯ И ВЯЧЕСЛАВА ЛИ. Научнометодический и теоретический журнал. 